\title{
Wrijvende meningen
}

Media en openbaarheid in Delft I850-1914

Fank van Vree

Op 7 januari 1885 verscheen het eerste nummer van een blad, dat zich had getooid met de etymologisch gezien nogal merkwaardige naam $\mathrm{De}$ Delvenaar. Uit de omstandige ondertitel Nieuws en Advertentieblad, gewijd aan de belangen van Huisgezin, School, Kerk en Staatzal de tijdgenoot onmiddellijk hebben opgemaakt uit welke hoek de wind hier waaide: die van het orthodoxe protestantisme, dat zich onder bezielende leiding van Abraham Kuyper in korte tijd een duidelijk herkenbare plaats in het openbare leven had weten te verwerven. De Delvenaar, zo heette het in een redactioneel ten geleide, zou tegelijk een 'bus', een echo, een tolk en een vriend zijn: een 'bus' voor vragen over staatkunde, maatschappij en kerk; een echo die de stemmen herhaalt die in deze veelbewogen maatschappij te horen waren; een tolk 'welke de stemmen in de spraakverwarring van den dag vertaalt'; en een vriend, 'die U bezoeken komt, om U te vertellen wat er alzoo nieuws in de wereld is' en ook 'te waarschuwen voor vijanden die U in Uw huisgezin belagen'. En het redactioneel besluit: 'Huisgezin, school, kerk en maatschappij zijn de vier factoren die in het volksleven voorop treden; de libesralen hebben het verband daartusschen verbroken."

Bij de vreugdevolle en heldere woorden waarmee de verschijning van $D e$ Delvenaar werd aangekondigd, zou men bijna vergeten dat het hier feitelijk ging om een voortzetting van het al vijftien jaar bestaande Advertentieblad voor Delft en Omstreken. Dit blad was opgericht in 1869 , onmiddellijk na de afschaffing van het Dagbladzegel, de zware belasting op drukwerk die al decennialang een rem vormde op de ontwikkeling van de pers in Nederland. Het was een flinterdun blaadje, geheel bedrukt met advertenties en aanvankelijk hoofdzakelijk gratis verspreid. Een paar maanden later was het evenwel al uitgegroeid tot een vier pagina's tellend krantje, op tabloid formaat, met binnenlands én buitenlands nieuws, een blaadje dat ook al snel kleur bekende door een onmiskenbaar christelijk-historisch standpunt in te nemen tegenover de vragen van de dag, te beginnen met de opgelaaide schoolstrijd. 
De naamsverandering die het Advertentieblad in 1885 onderging, bevestigde de groeiende betekenis van het politieke en levensbeschouwelijke element in de kolommen van het blad. Juist zoals het landelijke orgaan van de antirevolutionaire beweging, De Standaard, door Kuyper persoonlijk bestierd, plaatste De Delvenaar bij commentaren een 'driestar'-icoon en besteedde zij veel aandacht aan verwante instellingen en organisaties, zoals blijkt uit de publicatie van een achtdelige serie - paginagrote - artikelen over een jaarvergadering van de vakorganisatie Patrimonium.

De ontwikkeling van de antirevolutionaire pers in Delft is in meer dan een opzicht illustratief voor de geschiedenis van de publieke sfeer in Delft in de jaren 1850-1914 - een geschiedenis waarvan het beginpunt moet worden gezocht in de politieke en maatschappelijke verhoudingen rond het midden van de negentiende eeuw, toen economisch herstel na jaren van bittere armoede en massale werkloosheid voor een nieuwe dynamiek zorgde. ${ }^{2}$ De bevolking van de stad - inclusief de uitbreiding aan de grenzen van de gemeente - verdubbelde de volgende halve eeuw tot veertigduizend zielen en in diezelfde jaren ontwikkelde zich een moderne economische infrastructuur, met een omvangrijke industriële en dienstensector en een gedifferentieerde beroepsbevolking.

Lokale drukkers en uitgevers beantwoordden deze maatschappelijke veranderingen met publicitaire initiatieven, met het oog in eerste instantie vooral gericht op de advertentiemarkt. Behalve de antirevolutionaire Delvenaar moeten ook de progressieve liberale Delflandsche Courant en de katholieke Nieuwe Delfssche Courant in de eerste plaats worden beschouwd als de vrucht van commerciële ambities in een expanderende economie. De ontwikkeling van de lokale pers weerspiegelde evenwel niet alleen de sociaaleconomische veranderingen, maar ook de transformatie van de stedelijke openbaarheid als zodanig.

\section{Een liberaal-conservatief bolwerk}

Op het achterblad van een van de eerste nummers van de Delflandsche Courant, opgericht in 1855 , stond onder het kopje 'Korrespondentie' de volgende mededeling te lezen:

'Het ingezonden stuk, geteekend: "een Postdirecteur" zal in ons volgend $\mathrm{N}^{\circ}$ geplaatst worden, daar wij gaarne wrijving van gedachten bevorderen, als het beste middel om eene zaak behoorlijk toe te lichten en ons te vrijwaren voor den schijn van eenzijdigheid.' 
Een bericht van niks, zeker, maar niettemin veelzeggend. Aan de onbeduidende mededeling lag namelijk een opvatting ten grondslag die eerst in deze periode ook in de pretentieloze kleinstedelijke pers tot uitgangspunt leek te zijn verheven: een forum te willen zijn voor het openbare debat. In het allereerste nummer van de Delflandsche Courant had de uitgever een vergelijkbaar geluid laten horen. De positieve reacties bij het verschijnen van de krant beschouwde hij als een dubbele aanmoediging

'den inhoud van dit blad voor allen zoo belangrijk mogelijk te maken en (..) tijd noch moeite te sparen om getrouwelijk het door haar opgegeven Programma te volgen, en de wetenswaardigste berigten of gewigtigste openbare handelingen in zijne kolommen op te nemen; van den goeden smaak harer lezers verwachtende, dat zij aan dergelijke mededeelingen de voorkeur zullen geven boven zouteloze aardigheden of bontgekleurde brand- en moord-berigten.

$\mathrm{Bij}$ het mededeelen van beschouwingen of beoordeelingen zal immer eene strenge onpartijdigheid worden in acht genomen, en zonder der waarheid te kort te doen, alles vermeden worden wat het persoonlijk gevoel kan kwetsen of de individueele belangen zoude kunnen krenken. Daarom stelt de Redactie met vertrouwen dit blad open voor elke vrijmoedige en eerlijke beschouwing van de gewigtigste belangen der Stad onzer inwoning en der Gemeenten waarvan deze het middelpunt is. ${ }^{34}$

Dit citaat, waarin het ideaal van burgerlijke openbaarheid zo kernachtig verwoord is, vormde een echo van de verklaringen waarmee andere liberale bladen, zoals De Gids en de Nieuwe Rotterdamsche Courant, in voorgaande decennia hun redactionele positie en zelfs hun bestaansrecht hadden verdedigd. Deze opvattingen sluiten vrijwel naadloos aan bij Habermas' beschrijving van de 'Öffentlichkeit in ihrer liberalen Gestalt'. Conform dit ideaal zou de openbare sfeer voor ieder toegankelijk zijn en zouden niet status, rijkdom of macht maar redelijke argumenten in het maatschappelijk debat de doorslag geven - twee essentiële punten, in de ogen van Habermas. Want precies de beginselen van universaliteit en rationaliteit moesten de nieuwe burgerlijke samenleving haar noodzakelijke samenhang verschaffen. Alleen in een openbare en rationele gedachtewisseling kunnen botsende particuliere belangen en inzichten met elkaar worden verenigd op een wijze, die voor alle deelnemers aanvaardbaar is. Machtsuitoefening was alleen dan legitiem indien zij publiekelijk controleerbaar was en onderwerp kon zijn van een debat, waarin onafhankelijkheid en redelijkheid van cruciale betekenis waren.'

Door de wijze waarop de krant zich aan het publiek presenteerde, liet de Delflandsche Courant - een initiatief van drukker en uitgever J.C. Perk, 
wiens familie ook later die eeuw nog van zich zou doen spreken - zich kennen als liberaal blad. In een van de volgende nummers zou de krant haar positie nog scherper afbakenen, door zich te keren tegen de roep om de Kermis af te schaffen. Met een snier naar christelijke politici pleitte de krant voor de 'veredeling' van de massa door kunst en lichaamsbeweging: 'geen afschaffing, maar aanschaffing van hetgeen het volk ontbreekt en zelf niet bekostigen kan' - eraan toevoegend dat dit heel wat moeilijker is dan geld geven voor de 'bekeering der heidenen of Chinezen'.

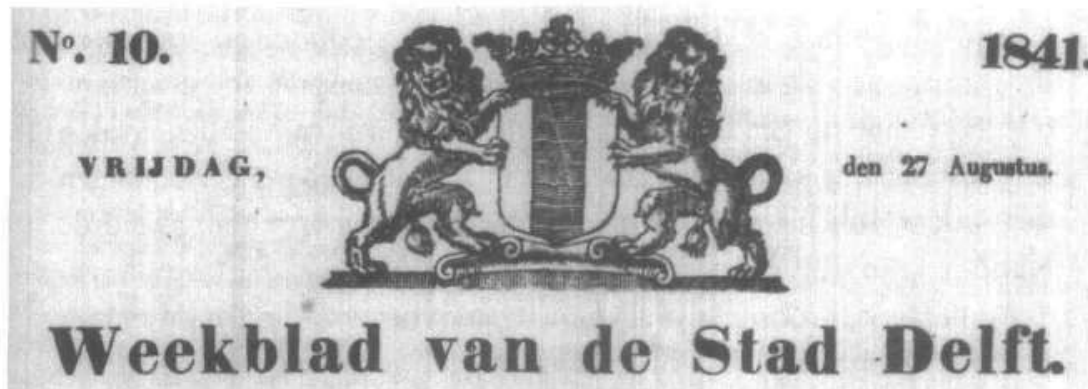

\section{NOTIFICATIR.}

BURGEMEESTER \& WFTHOUDERS nen STAN DE.L.FT hebben bet genoegeb bij deze aan de lngezetenee kennia te gerpa, dat door Han Ed. Aehtb. van Zijne Ma. jeateit den KOVINO, tijdens Hoogutdesuelís woo grwenseht als heugelfjk besoek op eergister, de herhanalde rerselse. ring is ontrangen van Zjper Mrjesteits tevredenheidover do ongeveinade- algeneene- en hartelijke bewijzeh ran hooge achitiog. petrouwheid en liefde, door de Burzeril mooge ploogrtdenselfe. Persoon en Stamhais, aan dep roor Hoogstdes

Burgemeester en Withosders maken wich deze zelegenbeid ten natte, om deo Ingezetenen hannen dank to bethigen voor de door hun gegereh openlijke blijken van hunne hulde en verknochtheid aan Netrlands beainden KONING, en voor alles wat door hun, henevens de Eerewacht en de Schatterij, is torgrhapt tot den luister ran dezes dag, in tat de yerhooging der feestrrengde tor gelegenheid van Hoozstdenalif, bezoek alhies.

Des.rv, den 20 Augustua I I I1. vix RERKE,L. Ter ordonanantie van dezrles.

Weekblad van de Stad Delft, de directe voorloper van de Delftsche Courant. In deze jaren had het blad een

semi-officiële status, die het pas verloor toen de politiek democratiseerde

te zien in de zaal harer rergoderingeb t die Ber werd haar gende bijzonderheden medederlen:

De annsprask aan Z. M. . hij gelegenheid derandientie nan de Hegering deze: Stad, door des Fd. Artith. Niter Burgemeestec gedaan, wa in de volgende bewoordingen ain in de aual harer vergadering

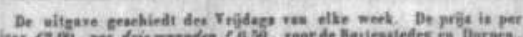

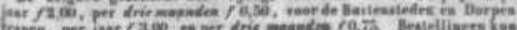

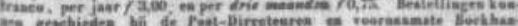
teiseres.

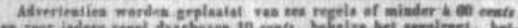

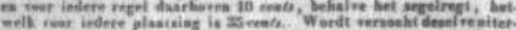

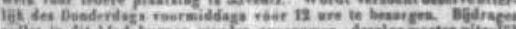

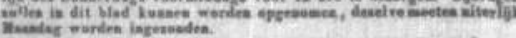

De persoon ran JOsE.PH LUDOWICH sTOLTEFUS, ' het eerst toegedacht doer Uwe Maj., die deor het bexoemordt, in dexalf, belang, veraocht, zich soo spoedig | angeljik asntemeiden ter Stads Secretarie. kre van alle eorden des Rijks, de behoeften van alles kre van alle eorden des Rijks, de beboeften van
nil krunes, - bet welsijn van alles bevorderen: Xink I de band, hierdoor gelegd, aluit Vorat a Volk navaw aan eeo : - Moge die ernatige wil, om het gelak vas gebeel het Vaderland to berorleren, ook voor dese Stad rijke rruebten drazen, en zili door de hooge besebervaing van $U_{w s}$ Maj, het vnrlies siea vargoedeb, dat xil geteden heeft, bij de verplantsiag van eres inrigting, die geieded hech, blj de verpiantsiag van ecue inng giag, die

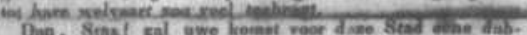
bele weldead wereth. - Dan zal sich Dwe Maj. cen duarzasin gedenkteeken in de barten onzen Ingezetenen bab. ben gesticht I Dan aal de Burgerij ook de Regering dank; a. die de vrijmoedige tolk was van bare enrbiedigo wenechen. Xinx! ik necia de vrijheid de belangen deaer Btad nog. naals Ciwer Maj. an te bevelen.

- Bo het dejeanér, van stade wege an Z. M. wange: boden, was Z. Exe. de Heer Gouvernear der Provineie erplaatst an de mgterhand van Z. M., en an de linkergijde was Z. E. de Heer Genrnal-Majoor Joakth. Beorts, Prorineiale Konumandant $\operatorname{ran}$ Zuid-Holland, gesetes ; ovet Z. U. warrn geplantat de B. . A ehtb, Heereb Burgemeenter es Wethouders. Alan het dejeunér namen voorts drel, de

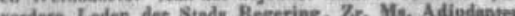

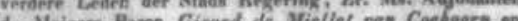
de Mnjoors Baron Gimrt dr Miefher can Coeboors en Merkes. Z. Rke. de Heer Vice-Admirant Ziereogel, de Hrer Griffier der Provineiale Staten ten Zeldam Gantreyd. de Heer Lait. Kolenel Dirwetear der Stapel-en Conntruetia Magaxilnen, de Heeres Hoofi-Offeieren van de leorpaen alhier in garnisoen, de Heer Majoor Kommandant der dienetdoende Sehatteri], de Heeren Kantonregter en Giriffier. enz.

De. Atandaart der Ferewneht te paard, welke voorloopig Itrn hoixe vin den Kommapdant derselve, de Heer Mans, zedeposeerd was. is Zatardag middag j.I. , door de Leden

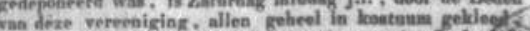

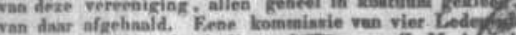
derarlver midden, beeft dit andentyon $\mathbf{Z}$. M. b.

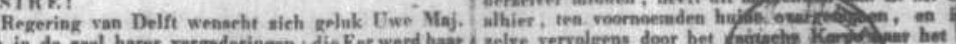

\section{.}

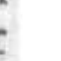


De Delflandsche Courant zou het nauwelijks een jaar volhouden. De krant, die tweemaal per week verscheen met enkele pagina's nieuws en advertenties, bleek niet opgewassen tegen haar gematigde, sedert I84I verschijnende concurrent, de Delftsche Courant, die in deze jaren binnen de prinsenstad een min of meer officiële status bezat. Zo verschenen de Handelingen van de gemeenteraad lange tijd als bijlage bij het meerdaagse blad, tezamen met andere mededelingen vanwege het stadsbestuur. De uitgevers van de Delftsche Courant en haar directe voorlopers ${ }^{7}$ waren niet alleen de officiële drukkers van de stad, maar ook van de Koninklijke Akademie (de voorganger van de Technische Universiteit) en het Hoogheemraadschap Delfland. Door haar semi-officiële karakter verkeerde de Delftsche Courant in een voordelige positie ten opzichte van mogelijke concurrenten, zoals de Delflandsche Courant, die zuchtte onder de zware belasting op drukwerk en een dergelijke financiële ondersteuning moest ontberen.

Rond het midden van de eeuw liep de Delfsche Courant in haar kolommen nog zelden te koop met uitgesproken politieke standpunten. Kleuring vond het publiek vooral in de rubriek buitenland, waar de redactie zich blijkbaar openhartiger over de kwesties van de dag meende te kunnen uitlaten. Zo werd de lezer vergast op woorden van instemming met het hervormingsbeleid van de Russische tsaren, met uitroeptekens bij de heersende godsdienstige onverdraagzaamheid in Spanje, en, later, bewonderende adjectieven in stukken waarin Garibaldi ten tonele werd gevoerd. Met betrekking tot de binnenlandse politiek moest daarentegen dikwijls tussen de regels door worden gelezen - om vervolgens te stuiten op een toon die zich het best laat karakteriseren als gematigd liberaal en nationalistisch, hier en daar neigend naar een meer conservatief standpunt.

Met haar bezadigde lijn volgde de Delftsche Courant - die na de snelle ondergang van de Delflandsche Courant weer een monopoliepositie innam - de betrekkelijk rustige ontwikkelingen in de stad. De grondwetswijziging van 1848 , die het begin markeerde van de politieke modernisering van Nederland, veroorzaakte ook in de Delftse politiek nauwelijks beroering. Alleen De Echo des Volks, een radicaal-democratisch weekblad, probeerde onder het motto 'Orde, Vrede, Vrijheid, in alles de Wet, en Zelf zij de Man ${ }^{18}$ het premoderne, populistische revolutionaire sentiment op te stoken dat een paar jaar eerder, tijdens het aardappeloproer van midden 1845 , in Delft had gewoed. Toen was dat beantwoord met de inzet van een regiment dragonders, met het doel een verdere plundering van levensmiddelenwinkels te voorkomen.' Het was duidelijk dat de Delftse burgerij zich meer herkende in de gepaste uitingen van vreugde die de Delftsche Courant aan de dag legde bij de 'heuglijke tijding' van de ommezwaai van Koning Willem II. 'Eere den vorst die de wenschen der natie tot zich heeft laten doordringen." 
Mr. H. van Berckel, telg van een vermogende katholieke patriciërsfamilie, wethouder (1824-1840) en

burgemeester (1840-1848) van Delft. Van Berckel stond model voor de gematigde regentenfamilies die de stad tot in de jaren zestig beheersten en ook onder de nieuwe verhoudingen nog decennialang een belangrijke rol in het openbare leven zouden spelen. Portret door C. Cels (1828). Bron: V. Schipper en F. van Vree, 'De modernisering van een traditionele Hollandse stad. Delft tussen 1850 en 1940', in Delft wordt modern. Architectuur en stedebouw 1850-1940 (Delft 1990)

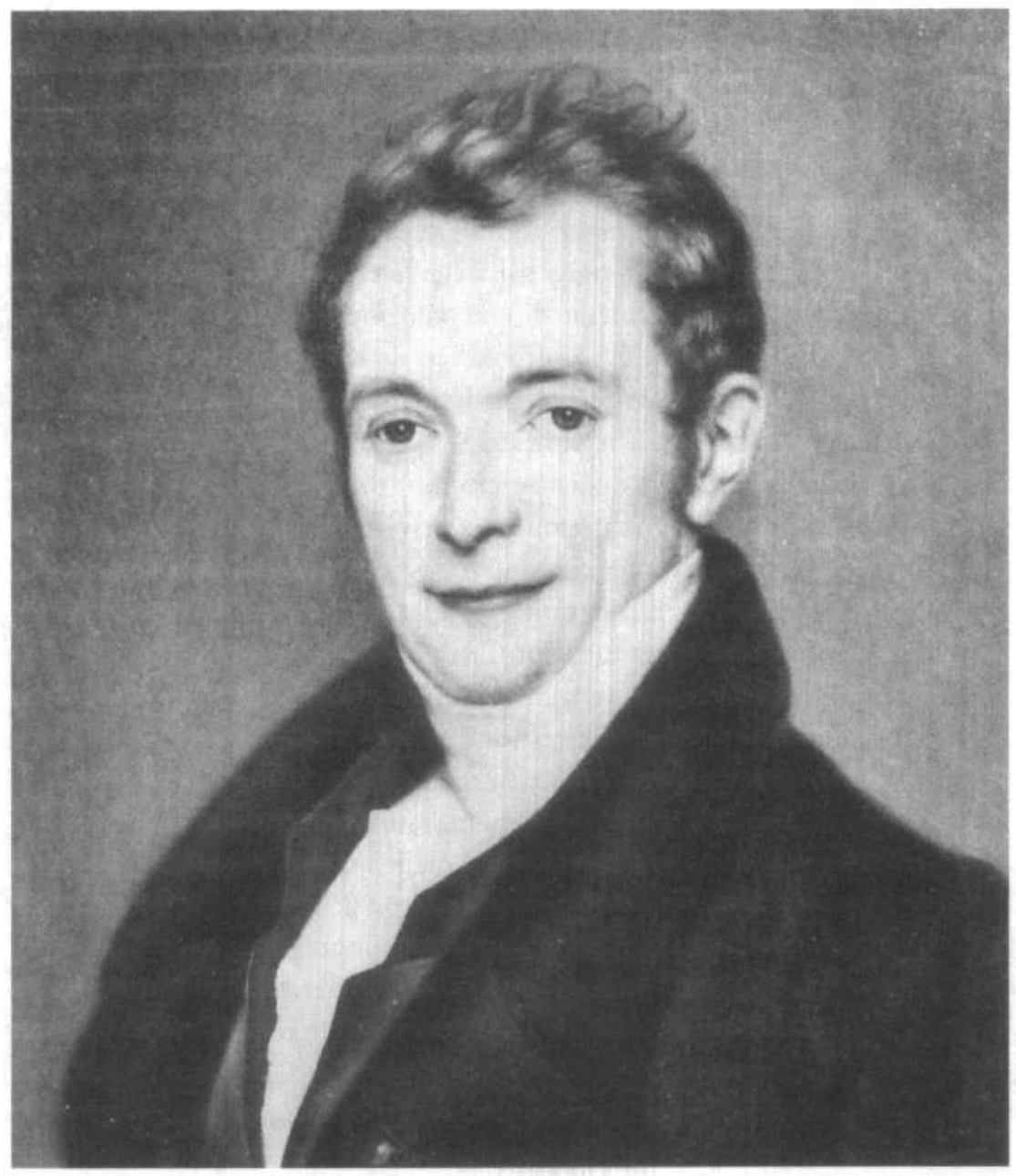

Deze reactie is - zoals gezegd - typerend voor de krant zowel als voor de stedelijke politieke verhoudingen: hoewel op nieuwe leest geschoeid, brachten de eerste verkiezingen onder de nieuwe Gemeentewet weinig verandering in de samenstelling van de raad. De overgrote meerderheid van de zeventien verkozen leden zat al eerder in de raad of behoorde tot de traditionele raadsgeslachten; families van juristen en fabrikanten dikwijls, zoals Van Kuyk, Van Berckel, Hartogh Heys, Hoekwater, Maas Geesteranus, Van der Mandele en Overgaauw Pennis, naast het oude orangistische regentengeslacht Van der Goes van Naters. Zij vormden een elite die Delft met een opmerkelijke continuïteit bestuurde. De families waren vaak door onderlinge huwelijken en zakenrelaties met elkaar verbonden: tussen 1850 en 1900 leverden zij niet minder dan 3I raadsleden, die gemiddeld twintig jaar zitting hadden en veertig procent van de zetels bezet hielden." Machinefabrikant 
H. Hartogh Heys jr., gedurende $4 \mathrm{I}$ jaar raadslid, en de Van Berckels, een familie van zeer vermogende katholieke industriëlen, die van I8II tot 1903 vrijwel onafgebroken een raadszetel bezetten, spanden in dit opzicht de kroon. Al deze notabelen bekleedden ook talrijke functies in het sociale en culturele leven, waarbij hun levensbeschouwelijke achtergrond een belangrijke rol speelde. Een aanzienlijk aantal van hen vervulde ook kerkelijke ambten: zeven van de negentien raadsleden waren in 1870 ouderling, diaken of kerkvoogd van de Nederlands Hervormde of Waalse Gemeente. ${ }^{2}$

Hoewel de stad dus nog geruime tijd een bolwerk van gematigd conservatisme bleef, beheerst door traditionele raadsgeslachten, en de liberalen er pas in de jaren zeventig in slaagden een overheersende positie in de gemeenteraad te verkrijgen - in hun kielzog gevolgd door confessionelen en, veel later, socialisten - nam de betrokkenheid van de kiesgerechtigde burgers bij de gemeentepolitiek al direct na 1848 toe. ${ }^{13}$ Dat valt af te leiden uit de hoge opkomstcijfers bij verkiezingen en de oprichting van kiesverenigingen met kandidatenlijsten en bijbehorende propaganda. Te beginnen met de conservatief-protestantse kiesvereniging 'Koning en Vaderland', die samen met haar opvolger 'Eendracht maakt Macht' in staat was tot in de jaren zeventig van de vorige eeuw een stempel te zetten op de gemeentepolitiek. Al die jaren gold het district Delft ook bij de verkiezingen voor de Tweede Kamer als conservatief. ${ }^{14}$

De betrekkelijk neutrale kleur die de Delftsche Courant tot ver in de negentiende eeuw kenmerkte, was dan ook minder een gevolg van ingesleten matheid dan van de heersende verhoudingen. De krant toonde zich wel degelijk betrokken, maar de stedelijke politiek en de verkiezingen hadden nog een sterk persoonlijk karakter; van moderne partijpolitieke verhoudingen was nog geen sprake. Zo kon het voorkomen dat iemand op zowel de conservatieve als de liberale kandidatenlijst stond. Pas in de loop van de jaren zeventig veranderde dit en was niet langer de persoon maar de politieke richting bepalend voor de (her)verkiezing tot raadslid. En ook in Delft was het de 'schoolquaestie' die fungeerde als breekijzer in de bestaande politieke verhoudingen. Het proces dat toen in gang werd gezet, zou de conservatieve stroming langzaam maar zeker van haar invloed beroven. Halverwege de jaren zestig organiseerden eerst de liberalen en vervolgens ook de antirevolutionairen zich in de kiesverenigingen 'Nederland' respectievelijk 'Nederland en Oranje'. De katholieken volgden dit voorbeeld met de oprichting van de kiesvereniging 'Recht voor Allen'. De traditionele raadsgeslachten moesten inschikken; in de jaren tachtig kregen voor het eerst gewone burgers toegang tot het college van burgemeester en wethouders."

De afbrokkeling en uiteindelijke ondergang van het 'herenbolwerk' - de overmacht van traditionele bestuurders in stedelijke en maatschappelijke organisatie, waarin zowel katholieken en hervormden als conservatieven en 
liberalen deelnamen - was evenwel niet louter een politieke zaak. Ook op andere fronten werd gestreden, te beginnen op kerkelijk gebied. Zo leidde de invoering van verkiezingen binnen de Hervormde Kerk in 1870 ertoe dat de oude elite uit de kerkenraden werd verdreven. De toeneming van de bevolking en - vooral - de economische ontwikkelingen die de stad doormaakte, creëerden niet alleen een snel groeiende middenklasse maar ook een nieuwe elite van handelaren, industriëlen en vrije beroepsbeoefenaren, die zich vooral vanaf de jaren tachtig met kracht in het maatschappelijk leven deden gelden. In diezelfde tijd werd het censuskiesrecht uitgebreid, wat volop mogelijkheden bood voor kandidaten die niet tot het establishment behoorden.

\section{Partijen, media en openbaarheid}

De metamorfose van de stedelijke openbaarheid die zich vanaf de jaren zeventig in nauwe samenhang met de ingrijpende veranderingen op sociaaleconomisch gebied in snel tempo voltrok, vond haar weerslag en - gedeeltelijk - ook haar oorsprong in de ontwikkeling van de lokale media. De Delftsche Courant, spreekbuis van het bezadigde liberalisme en gematigde conservatisme, had in de ogen van de politiek en religieus bewuste en strijdbare confessionele middengroepen afgedaan. Hoewel de krant nog lange tijd onbetwist de grootste zou blijven, kreeg ze in toenemende te maken met concurrentie, zowel van de landelijke dagbladpers als van politiek en religieus georiënteerde stedelijke bladen die hun bedoelingen niet onder stoelen of banken staken. De Nieuwe Delftsche Courant bijvoorbeeld, opgericht in 1875 - zeer vroeg in vergelijking met andere regionale en lokale katholieke kranten - zette zich al in het eerste redactioneel scherp af tegen bladen die niets anders voor ogen leek te staan dan 'den Christen ergernis te geven, om den Katholiek te beleedigen in wat hem het heiligst is: den Godsdienst; om met den geloovigen Protestant den draak te steken, - in het kort, om het ongeloof te verspreiden'.' ${ }^{16}$ Een paar weken later werden man en paard genoemd: het liberalisme 'dat schatten vernield, immer afbreekt en nooit opbouwt. ${ }^{17}$

Nog in hetzelfde jaar waarin het vijftien jaar oude Advertentieblad voor Delft en Omstreken werd omgedoopt in de antirevolutionaire krant De Delvenaar, resulteerde de heftige verkiezingsstrijd tussen het confessionele blok en de liberalen, in de eerste doorbraak van de confessionele partijen in een grotere stad boven de grote rivieren. De Delftse kranten lieten zich in deze strijd niet onbetuigd. 'Dit jaar moet de groote slag geslagen worden om niet één, niet twee, neen alle opengevallen zetels te bezetten met mannen, die eens paal en perk zullen gaan stellen aan de verkwisting van de penningen 
der gemeente', schreef De Delvenaar strijdlustig. ${ }^{18}$ En de Nieuwe Delftsche Courant, spreekbuis van de aanzienlijke katholieke minderheid in de Prinsenstad, drukte haar lezers op het hart:

'Indien gij uw doel wilt bereiken, schrijft dan ook de geheele candidatenlijst der beide antiliberale kiesvereenigingen op uw stembiljet. Geen weifeling, geen halfheid ditmaal. Laat u niet terughouden door een ziekelijk gevoel van medelijden met de eventueel verslagenen ....'.

In deze vermaning openbaarde zich de diepe kloof die deze generatie scheidde van de vroegere politieke mores. persoonlijke sentimenten en opvattingen werden hier geofferd aan de beginselen. De ironie wil, dat de eerste politieke partij in Delft - een afdeling van de ARP - werd opgericht onder voorzitterschap van de zoon van het conservatieve kamerlid Bichon van IJsselmonde, die in 1840 zijn blijdschap had uitgesproken over het feit dat er in ons 'gezegend vaderland' geen partijen waren. ${ }^{20}$ De Delftse antirevolutionairen, die doorgaans de conservatieven hadden gesteund, zetten daarmee een onomkeerbaar proces van verandering in werking - hetgeen hen niet steeds in dank werd afgenomen, getuige de klacht, vele jaren later nog, in 1909, in de Delftsche Courant:

'Was het vroeger jaren een goed gebruik, dat aftredende leden, die door
kunde en toewijding, getoond hadden een raadszetel waardig te zijn,
door de tegenpartij onbestreden bleven, thans schijnt, door het drijven
der anti-revolutionairen, daarmede voorgoed gebroken te zijn. De
"christelijken" van dezen huize maken van elke verkiezing, ook van die
voor den Raad, een onedele stembussport, en men acht zich eerst recht
verdienstelijk, wanneer de meest bekwame mannen van hunne zetels
worden verdrongen ....'."

Parallel aan de partijvorming en de groeiende polarisatie in de lokale media was er vanaf de jaren zeventig sprake van een toenemende identificatie met gelijkgestemde bewegingen op nationaal niveau. Hoever men daarin ging, is hierboven reeds aangestipt in verband met De Delvenaar. De commentaren in die krant vormden in alle opzichten, wat betreft opzet, teneur en vormgeving, replica's van Kuypers befaamde driestarren in De Standaard. En zoals in de landelijke politiek werd de toon van het blad tegen de eeuwwisseling steeds harder en onverzoenlijker. De liberaal-conservatieve Delftsche Courant, die qua karakter dicht in de buurt kwam van de elders in dit nummer door Marcel Broersma beschreven Leeuwarder Courant, wist zich soms zichtbaar geen raad met deze houding van wat zij zag als religieuze en politieke onverdraagzaamheid. 
Tegen het einde van de eeuw vormden de liberalen evenwel niet langer het enige doelwit van de confessionele bladen. Ook de kleine kring van Delftse socialisten werd niet gespaard, in de pers zomin als op straat, want bij de inhuldiging van Wilhelmina in 1898 werden zij het slachtoffer van een heuse Oranjefurie. Onder de leuze 'Weg met de Socialen, leve Willemien!' werden hun woningen en bezittingen gemolesteerd. ${ }^{22}$ Socialisten, zo schreef de Nieuwe Delftsche Courant een paar jaar later, waren profiteurs, 'Staatsaanbidders' die hun kinderen ter opvoeding aan de Staat laten, 'daar zullen zij genummerd worden, evenals koopwaar in een magazijn' en 'worden opgekweekt in dezelfde socialistische gevoelens van goddeloosheid en barbaarschheid.' ${ }^{23}$

Hoewel de geschiedenis van de partijen, maatschappelijke organisaties en media in Delft in grote lijnen parallel liep aan de ontwikkelingen op nationaal niveau, kende deze toch ook een aantal duidelijk herkenbare lokale eigenaardigheden. Opvallend was bijvoorbeeld de late opkomst van de socialistische beweging. De Sociaal-Democratische Bond was in Delft weinig succesvol en zelfs de SDAP telde in 1903 nog maar 73 leden. Pas in 1909 behaalde de partij haar eerste raadszetel. ${ }^{4}$ Deze trage groei stond in schril contrast met de vroege geboorte van de orthodox-protestantse en katholieke bewegingen, gemarkeerd door De Delvenaar en haar directe voorloper (vanaf 1870) en de Nieuwe Delftsche Courant (1875). Deze eigenaardigheden krijgen des te meer reliëf wanneer men zich realiseert dat Delft in 1899 in het rijtje van geïndustrialiseerde steden in Nederland een vierde plaats bezette. Alleen in Maastricht, Schiedam en Enschede lag het aandeel van de industriële beroepsbevolking hoger. Met name de chemie, metaal, voedselverwerking en leerindustrie waren sterk vertegenwoordigd, en datzelfde gold voor de handel en de vrije beroepen, sectoren die nauw samenhingen met de centrale verzorgingsfunctie die de stad van oudsher vervulde. ${ }^{25}$

Voor de vroege opkomst van de confessionelen en de relatieve zwakte van de sociaal-democratie zou een aantal - deels speculatieve - verklaringen kunnen worden aangedragen. Ten eerste kan gewezen worden op de traditionele religieuze verscheidenheid. De Delftse bevolking bestond voor eenderde uit katholieken en kende een vrij grote Waalse gemeenschap, terwijl de Hervormde Kerk was geconfronteerd werd met een betrekkelijk groot aantal afgescheidenen en dolerenden. Deze verhoudingen zullen het 'kerkelijke bewustzijn' zonder enige twijfel hebben gevoed. Een andere mogelijke oorzaak van de trage opkomst van het socialisme in Delft zou men kunnen zoeken in de traditie van sociale harmonie. De stad was niet arm en kende van oudsher een hecht stelsel van sociale zorg, dat werd beheerd door de stedelijke elites waarvan ook katholieken deel uitmaakten. Ook de confessionele bewegingen die in de jaren zeventig opkwamen, toonden van aanvang af aan een sociaal gezicht. 


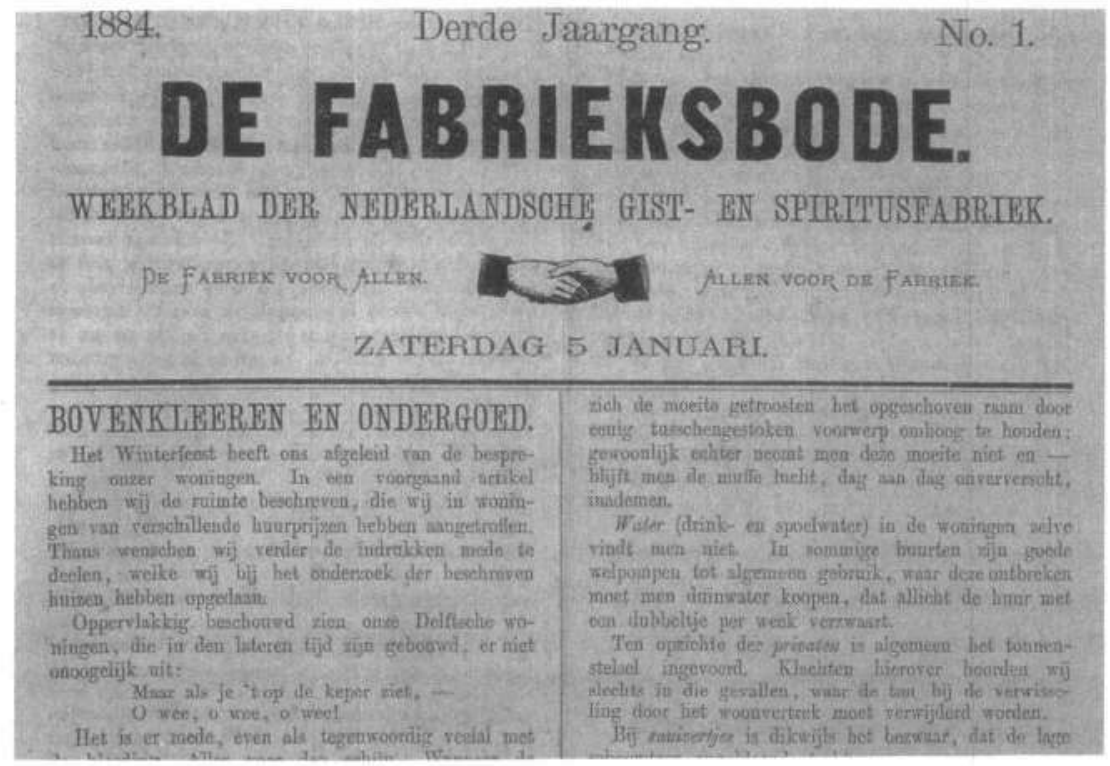

Dat laatste gold ook voor de nieuwe captains of industry die de prinsenstad een leidende rol in de modernisering van de Nederlandse economie bezorgden en met hun sociaal idealisme tot de verbeelding van velen spraken. De onbetwiste kampioen van deze praktische hervormers was de oprichter van de Gist- en Spiritusfabriek, J.C. van Marken. Die liet zich inspireren door het utopisch socialisme en omringde zijn onderneming met een soort tuindorp, coöperaties en niet minder dan twintig verenigingen. De leden kwamen overal vandaan: van een muziekkorps en een leesgezelschap tot een schermen jeugdvereniging. ${ }^{26}$ En Van Marken was, zoals gezegd, niet de enige sociale ondernemer in Delft.

Daarmee zijn we aangeland bij een andere lokale karakteristiek: de bloei van het radicale liberalisme, dat in Delft over een van de sterkste formaties buiten Amsterdam beschikte. De basis daarvan werd gelegd in de jaren zeventig, toen zich onder architecten en ingenieurs en het personeel van de - groeiende - Polytechnische School een levendige belangstelling voor sociale vragen aftekende. Vanaf 1885 kende Delft een radicaal-liberaal blad, onder de neutraal ogende titel Delfsche Opmerker. Nieuwsblad voor Delft en omstreken, gewijd aan de bevordering van gemeentelijke en staatkundige belangen. De krant, die zich opwierp als tolk van rede en geweten, vooruitgang en respect, werd uitgegeven door Waltmans, huisboekhandel én drukker van de Polytechnische School, maar ook uitgever van Multatuli.

In de Delftsche Opmerker - zo goed als in een aantal andere democratische bladen die in deze jaren in andere steden werden opgericht ${ }^{27}-$ leek het ideaal van de openbaarheid in zijn oorspronkelijke liberale gedaante te
De Fabrieksbode, opgericht in 1882 , was weliswaar het 'huisorgaan' van de Gist- en Spiritusfabriek, maar werd ook buiten de poorten van de fabriek gelezen. De directeur van de fabriek, J.C. van Marken, die zich tot zijn onvermoeibare praktische hervormingen had laten inspireren door het utopisme van Saint-Simon, gebruikte het blad namelijk ook om zijn verlichte denkbeelden te verbreiden 
herleven. 'Door wrijving der meeningen komt de waarheid aan het licht' schreef de redactie in haar eerste commentaar. De Delftsche Courant kreeg het verwijt de strijd met 'de mannen der overzijde' niet aan te gaan, terwijl de noodzaak daartoe zeker anwezig was. Alleen door het prediken van vooruitgang en verlichting kon 'het werk van voorvaderen' eer worden aangedaan. Nederland, eens het land der vrijheid, mocht 'zich niet weer krommen onder het gezag van het klerikalisme, hetzij het luistert naar de levende stem uit Rome of naar de doode letter der Dordtsche vaderen'. ${ }^{28}$ De krant, die verbonden was met de radicale 'Kiesvereeniging Nederland', wilde zich inspannen voor het algemeen belang én voor het individu: 'allen bouwen mede aan éénen tempel van aller geluk, van ware humaniteit'.

\section{Besluit: de dynamiek van het openbare leven}

De transformatie van de publieke sfeer die zich in de tweede helft van de negentiende eeuw voltrok, laat zich ook in andere dan politieke, religieuze en institutionele termen beschrijven. De verlichte opvattingen die aan de nieuwe concepten van openbaarheid ten grondslag lagen, waren immers nauw verbonden met een veel omvattender proces, typerend voor de moderne westerse beschaving en gericht op een systematische en rationele beheersing van de expanderende leefwereld. In de groei en uitbreiding van de Delftse pers is deze ontwikkeling ook terug te vinden. De kranten brachten inzicht en orde in de stroom van gebeurtenissen in de bekende wereld, ze boden een 'basisnarratief waarbinnen deze gebeurtenissen betekenis kregen en waaraan andere publicaties konden worden gerelateerd; ze structureerden de tijd, de loop en de perceptie, ze gaven inhoud aan het concept 'nieuws'. ${ }^{30}$ Kortom, de bladen weerspiegelden niet alleen de veranderingen in het openbare leven - in de meest brede zin van het woord -, ze gaven er ook vorm aan, alleen al door het naakte feit van het verschijnen, door hun inhoud, door hun discours, door de wijze waarop de werkelijkheid werd gerepresenteerd, berichten en meningen werden verwoord, geordend en verbonden, en - in de woorden van Walter Lippmann in zijn klassieke werk Public Opinion - door de 'pictures in our heads' die werden geformeerd.

Het zou te ver voeren dit fundamentele, cultuurhistorische proces hier uitvoerig te beschrijven, maar enkele punten zijn voor een goed begrip van de veranderingen in de Delftse openbare sfeer relevant genoeg hier gememoreerd te worden. In dit verband kan bijvoorbeeld gewezen worden op de grotere, intensere betrokkenheid bij het dagelijks gebeuren in de wereld - of het nu ging om uitvindingen, ongelukken, misdaden of buitenlandse politieke verwikkelingen - alsmede op de verandering van het perspectief vanwaaruit de kranten deze gebeurtenissen beschreven: als een samenhangend proces. In 
vrijwel alle kranten deed het 'panoramisch wereldbeeld' zijn intrede in de vorm van dagelijkse overzichten, waarin de grote actuele gebeurtenissen in samenhang werden beschreven en waaromheen vervolgens de 'verspreide berichten' per land werden geplaatst; een vorm van ordening die in veel kranten tot de Tweede Wereldoorlog zou blijven voortbestaan.

Een ander verschijnsel waarop in verband met de veranderingen in de publieke sfeer gewezen moet worden, heeft betrekking op de voorstelling van de stad zelf. Voor het eerst in de geschiedenis van de pers maakten de kranten het stedelijk leven zichtbaar, te beginnen in de uitvoerige verslagen van de gemeenteraad, de berichten van de burgerlijke stand en vooral de advertenties, die in aantal en omvang snel toenamen. Het 'moderne leven' werd in deze kranten in letterlijke zin openbaar: aankondigingen en verslagen van vergaderingen, lezingen, voorstellingen, meetings en vermakelijkheden. Juist aan dergelijke snelgroeiende rubrieken ontsproten wijdverbreide noties van de dynamiek en de maakbaarheid van het moderne stadsleven. De vorm waarin dit gebeurde, mocht, zeker rond 1870 , nog betrekkelijk primitief zijn, zoals de eindeloze hoeveelheid ogenschijnlijk bij elkaar geraapte nieuwsberichten en faits divers bewijzen - de stukken waren soms niet groter dan een paar regels. Tot 1869 althans, toen de afschaffing van het Dagbladzegel de deur openzette voor een snelle groei van deze rubrieken in aantal en oppervlakte.

En daar was ook behoefte aan. Een steeds groter deel van het dagelijks leven van de stad en haar inwoners bood de kranten stof tot schrijven, waarmee de stedelijke cultuur een dynamischer aanzien kreeg. Het resultaat hiervan was dat het beeld van Delft als 'nette Hollandse stad' geleidelijk en impliciet plaats maakte voor de voorstelling van de stad als plek van voortdurende verandering en rusteloze activiteiten, zowel op economisch als cultureel gebied.

De ontwikkelingen die zich in het betrekkelijk rijke Delftse medialandschap sedert het midden van de negentiende eeuw voltrokken, laten zich nu ook vanuit een ander perspectief bezien: als een onderdeel van een sociaal en cultureel moderniseringsproces, waarin zich zowel nationale als typisch lokale patronen weerspiegelden. Als orgaan van de traditionele gematigde elite kreeg de Delftsche Courant vanaf de jaren vijftig te maken met de representanten van opkomende sociale en politieke groepen. Twee van deze kranten wortelden in radicaal-democratische kringen: de eerste daarvan, de Delflandsche Courant (1856) lijkt te zijn voortgekomen uit 'autochtone' middengroepen, terwijl de Delftsche Opmerker (1885) vooral steunde op nieuwe 'professionals' in de snel expanderende moderne industrie en het academisch onderwijs.

Maar terwijl de basis van deze radicaal-democratische initiatieven te smal bleek om levensvatbare kranten te kunnen laten verschijnen, wisten de 
bladen die voortkwamen uit de anti-liberale stromingen, zich goed staande te houden. Delft werd daarmee een van de eerste steden waar de verzuiling zich al vroeg in het medialandschap uitkristalliseerde. Door zich los te maken van de vertrouwde standsverhoudingen en te trachten vanuit een kerkelijke inspiratie greep te krijgen op de stedelijke politiek, wisten het commercieel geëxploiteerde Advertentieblad Delft (1869) - dat zich al snel ontpopte als spreekbuis van het orthodoxe protestantisme en zich in 1885 omdoopte tot De Delvenaar - en de katholieke Nieuwe Delftsche Courant (1875) in betrekkelijk korte tijd wortel te schieten in de door traditionele religieuze tegenstellingen verdeelde Delftse bevolking. Daarbij keerden zij zich steeds scherper tegen het liberalisme en de liberale opvattingen over het openbare leven. De verschijning van de Delfsshe Opmerker, dat het ideaal van de openbaarheid 'in ihren liberalen Gestalt' nieuw leven probeerde in te blazen, werkte wat dat betreft als een rode lap op een stier.

Wie afgaat op de institutionele ontwikkelingen en de veranderingen in de toon en de inhoud van de stedelijke pers zal moeten vaststellen dat de publieke sfeer in Delft onmiskenbaar de symptomen vertoonde van de Strukturwandel die door Habermas is gekarakteriseerd als een Verfallsgeschichte van het burgerlijke ideaal van de late achttiende eeuw. Al dan niet in een poging de sociale basis van de democratie te verbreden en te versterken werd de publieke sfeer - in Habermas' ogen - in de loop van de negentiende eeuw gekoloniseerd door belangengroepen, massa-organisaties en overheden, ten koste van individuele, rationeel denkende burgers. In dit proces verwaterden de hooggestemde verwachtingen jegens de media als drager van de openbare mening en als vrijplaats van debat - verwachtingen die ook in de Delftse liberale bladen terug te vinden waren.

Uit deze schets blijkt echter dat deze veranderingen een onvermijdelijk gevolg waren van het zoeken naar nieuwe organisatievormen en andere politieke stijlen, die dikwijls niet waren geworteld in het verlichte denken, maar in religieuze en ethische sentimenten, culturele verschillen en scherpe sociale tegenstellingen. In die zin - verscheidene auteurs, onder wie De Haan en Te Velde, hebben er eerder op gewezen - is de interpretatie van deze ontwikkeling als een Verfallsgeschichte eenzijdig. Zij doet eenvoudigweg tekort aan het feit dat deze structurele veranderingen waardevolle resultaten opleverden voor de groepen die tot dan toe werden uitgesloten van het openbare leven, zoals de minder welgestelde bevolkingsgroepen, vrouwen, minderheden." 


\section{Noten}

I De Delvenaar. Nieuws en Advertentieblad, gewijd aan de belangen van Huisgezin, School, Kerk en Staat, 7 januari 1885 . Evenals zijn voorganger Advertentieblad voor Delft en Omstreken, werd het uitgegeven en gedrukt door J. van Oel jr.

2 Voor een algemeen overzicht van de Delftse geschiedenis in deze periode zie J.A. de Jonge, 'Delft in de negentiende eeuw. Van "stille nette" plaats tot centrum van industrie. Enkele facetten van de omslag in een locale sociaal-economische evolutie', in: Economisch en sociaal-historisch jaarboek XXXVII, 1974; J.W.L. Hilkhuijsen e.a., De stad Delft. Cultuur en maatschappij van I813 tot 19I4, Delft 1992; V. Schipper en F. van Vree, 'De modernisering van een traditionele Hollandse stad. Delft tussen 1850 en 1940', in Delft wordt modern. Architectuur en stedebouw 1850-1940, Delft 1990, p. 7-26.

3 Delflandsche Courant, 22 april 1855.

4 Idem, II maart I855.

5 Zie hiervoor F. van Vree, De politiek van de openbaarheid. Journalistiek en publieke sfeer, Groningen 2000.

6 Delflandsche Courant, 20 juni 1855.

7 De Delftsche Courant verscheen de eerste jaren onder wisselende (onder)titels. Voor de geschiedenis van deze kranten zie het (onvolledige) overzicht van de Delftsche pers van G.G. Kunz, 'Kranten en drukkerijen', in: Hilkhuijsen, De stad Delft, p. 237-247; alsmede W.P. Sautijn Kluit, 'Delftsche Couranten', in: Handelingen en mededeelingen van de Maatschappij der Nederlandsche Letterkunde, 1872, p. 82-88. Na het verdwijnen van de Delflandsche Courant zou de Delftsche Courant zich tooien met de onderkop Nieuwsblad voor Delft en Delfland (8 januari 1856 ).

8 Sautijn Kluit, 'Delftsche Couranten', p. 84. Zowel een redacteur als de uitgever zouden in verband met het blad worden gearresteerd en later wegens hoon en laster jegens een openbaar ambtenaar tot gevangenisstraf worden veroordeeld.

9 J. Rogier, 'Sociale geschiedenis van Delft 1840-1910', in: Mededelingen Vereniging voor Sociale Geschiedenis, nr. 20, nov. 1961, p. 2-3.

Io Delftsche Courant, 29 februari 1848.

II J.A. de Jonge, 'Delft in de negentiende eeuw', in: Economisch en sociaal-historisch jaarboek, 1974, p. 195.

I2 Voor een uitvoerige analyse van de Delftse elite: R. van der Laarse, 'Welstand, macht en aanzien. Het Delfts patriciaat', in: Hilkhuijsen, De stad Delft, p. II e.v.

I3 De verkiezingen van $185 \mathrm{I}$ boden, bij gebrek aan kandidatenlijsten, nog een chaotische aanblik: in de eerste ronde werden 675 stemmen uitgebracht op niet minder dan 225 kandidaten! Na herstemming was het resultaat een gemeenteraad bestaande uit tien conservatieven, drie liberalen en vier katholieken. Zie J. Talsma en R. van der Laarse, Accomodatiegedrag van lokale politieke elites bij de gemeenteraadsverkiezingen in de tweede helft van de negentiende eeuw (in Nederland in het algemeen en in Delft in het bijzonder), ongepubliceerd verslag, Amsterdam 1986; vergelijk A.J. Potse, "Men is blijkbaar bij ons van alle markten thuis'. Verkiezingen in Delft 1848-1887', Ongepubliceerde doctoraalscriptie RU Utrecht 1986. 
14 A. van der Wees, I866-1980 Grepen uit de geschiedenis van de A.R.P.-Delft, Delft I980, p. 30.

Is Van der Laarse, 'Delfts patriciaat', p. 23.

I6 'Aan onze Lezers', Proefnummer Nieuwe Delftsche Courant, 23 mei 1875.

17 Idem, 6 juni 1875 .

18 De Delvenaar, 10 augustus 1885 .

19 Nieuwe Delftsche Courant, 19 augustus 1885. De antirevolutionairen behaalden zes zetels, de katholieken vier, de liberalen zes en de conservatieven vijf.

20 Van der Wees, ARP-Delft, p. 43.

2I Delftsche Courant, 8 juli 1909.

22 G.J. ten Velden, Veertig jaren strijd. Beknopt overzicht van de geschiedenis der afdeling Delft van de Soc.-Democr. Arb. Partij, Delft 1938.

23 Nieuwe Delftsche Courant, is mei 1904.

24 Ten Velden, Veertig jaren strijd, p. 45.

25 P. Kooy, 'Urbanization. What's in a name', in: H. Schmal (red.), Patterns of European Urbanisation since I50o, Londen I98I, p. $4 \mathrm{I}$ e.v.; P. Kooy, 'Peripheral cities and their regions in the Dutch urban system until 1900', in: The Journal of Economic History, XLVIII 2, 1988, p. 357-371.

26 J. Muntendam, Loon naar werken. Enkele sociale aspecten van het werk van J.C. van Marken, Deventer 1971; J.C. van Marken, Het Agneta-park en de Naamlooze Vennootschap Gemeenschappelijk Eigendom, Delft 1884 .

27 Van Vree, Politiek van de openbaarheid, p. 26 e.v.

28 Delftsche Opmerker, 23 december 1885.

29 Idem, 30 december 1885.

30 Vgl. J.D. Popkin, News and politics in the age of revolution. Jean Luzac's 'Gazette de Leyde', Ithaca NY 1989.

3I I. de Haan en H. te Velde, 'Vormen van politiek. Veranderingen van de openbaarheid in Nederland 1848-1900', in: Bijdragen en mededelingen betreffende de geschiedenis der Nederlanden (BMGN) CxI/2, 1996, p. 199-200. Voor een kort overzicht van de actuele discussies over Habermas' concepten, zie ook Van Vree, De politiek van de openbaarheid, alsmede C. Calhoun (ed.), Habermas and the Public Sphere, Cambridge Ma. 1992. 